\title{
The Enhanced Effect of Oplopanax elatus Nakai on the Immune System and Antitumor Activity
}

\author{
Jin Woo Hur, Eun Hee Cho, Bo Kyung Lee, Uiyoung Lee* and ${ }^{\dagger}$ Taek Joon Yoon \\ Dept. of Food \& Nutrition, Yuhan University, Bucheon 422-749, Korea \\ "Sanyacho-Nongwon, Namyangju 472-848, Korea
}

\begin{abstract}
The present study is designed to explore an anti-tumor activity on crude extracts of Oplopanax elatus. Water extractions of Oplopanax elatus were performed at $100^{\circ} \mathrm{C}(\mathrm{OeE}-100)$. OeE-100 doses up to $62.5 \mu \mathrm{g} / \mathrm{ml}$ had no cytotoxicity on the tumor cell lines in vitro. In experimental lung metastasis of colon26-M3.1 carcinoma or B16-BL6 melanoma, the prophylactic intravenous (4 100 $\mu \mathrm{g} / \mathrm{mouse})$ or oral ( $2 \mathrm{mg} / \mathrm{mouse})$ administration of OeE-100 significantly inhibited tumor metastasis as compared with tumor controls. Peritoneal macrophages stimulated with OeE-100 produced various cytokines such as TNF- $\alpha$, IL-6 and IL-12. In an analysis of NK-cell activities, i.v. administration of OeE-100 (10 100 $\mu \mathrm{g} / \mathrm{mouse})$ significantly augmented the cytotoxicity to YAC-1 tumor cells. Vaccination of mice with boiling-treated tumor cells (BT-vaccine) in combination with OeE-100 (100 $\mu \mathrm{g} /$ mouse) showed higher inhibitions in tumor metastasis when compared with the mice of BT-vaccine treatment. In addition, the splenocytes from OeE-100 admixed BT-vaccine immunized mice secreted a higher concentration of Th1 type cytokine such as IFN- $\gamma$. These results suggested that the OeE-100 stimulated immune system and was a good candidate adjuvant of anti-tumor immune responses.
\end{abstract}

Key words: Macrolepiota procera, macrophage, NK-cell, metastasis, synergistic activity

\section{서 론}

악성 종양의 극복방법으로서의 하나인 면역요법(immunotherapy)은 생체 내의 면역세포를 이용함으로써 부작용이 적 은 가장 자연적인 치료방법으로 인정되고 있다. 그러나 악성 종양세포의 면역회피 기전은 암에 대한 면역요법의 약점이 되 고 있다(Ahmad 등 2004; Gutzmer 등 2004). 종양에 대한 이러한 면역요법의 약점은 종양에 대한 숙주의 면역계를 자극시키 는 biological response modifier(BRM)의 개념이 확립된 후, 그 의 이용에 의하여 실험적 혹은 임상적으로 종양의 치료 가능 성을 제시하고 있다(Bisht 등 2010). 실제 실험보고에 의하면 면역 자극물질에 의하여 활성화된 작동세포인 natural killer(NK) cell 및 macrophages와 같은 선천면역계의 작동세포를 활성화 시킴으로 암의 증식 및 전이를 유의하게 억제하는 것으로 보고되고 있다(Fisher \& Yang 2002; Wasser SP 2002). 따라서 최근 세계 각국에서 암의 극복을 위하여 전통적으로 사용한 약제 등 천연물로부터 면역계를 활성화시키는 작용을 가지 는 물질의 탐색에 관한 연구가 고조되고 있다(Ohno 등 2001; Stauder \& Kreuser 2002; Oh \& Lee 2012). 특히 우리나라는 전통적으로 민간 및 한방에서 여러 식물을 약제를 사용하여 온 경험이 있기에(Oh \& Lee 2012, Kim 등 2012), 이러한 후 보 생약을 현대 과학에 접목하여 결과를 유도한다면 이는 이후 임상에 적용할 수 있는 약재로 가능성이 클 것으로 생 각한다.

\footnotetext{
${ }^{\dagger}$ Corresponding author: Taek Joon Yoon, Dept. of Food \& Nutrition, Yuhan University, Bucheon 422-749, Korea. Tel: +82-2-2610-0804, Fax: +82-2-2610-0808, E-mail: yoon_tj@yuhan.ac.kr
} 
선천적 면역계에서 암세포에 대하여 살해력을 가지는 대 표적 작동세포로는 주로 macrophages 및 $\mathrm{NK}$ cell 등이 있으 며, macrophage가 생산하는 cytokines는 주로 이들 작동세포 의 활성화에 관여한다. 활성화된 macrophage는 반응성 산소 중간 대사산물(reactive oxygen intermediates; ROIs), 산화질소 (nitric oxide; NO) 및 효소 등을 생산하여 암세포를 직접 살해 할 뿐 아니라(Murray \& Nathan 1999), 선천면역계 혹은 적응 면역계의 암에 대한 작동세포의 활성화를 유도하는 cytokine 을 생산한다(Trinchieri G 1995; Gough 등 2001). 활성화된 macrophge가 생산하는 tumor necrosis factor(TNF)- $\alpha$ 는 major histocompatibility complex(MHC)의 발현을 촉진함으로 항원 제시능에 관여하며(Knutson \& Disis 2005), interleukin(IL)-12 는 NK세포와 같이 암세포 살해활성을 획득한 작동력을 가지 는 면역세포의 활성화에 기여한다(Weiss 등 2007; Chino 등 2005). 따라서 선천면역계에서 macrophage 및 NK-cell은 종양 세포의 증식을 억제하는 가장 중요한 작동세포로 인정되고 있다(Gough 등 2001; Yoon 등 2003).

악성 종양세포에 대한 획득면역계의 활성화가 억제되는 것은 암세포의 면역회피기전이며, 그중에서 암세포의 낮은 면역원성은 암에 대한 획득면역의 유도에서 가장 중요한 난 제 중의 하나이다(Ahmad 등 2004; Gutzmer 등 2004). 악성종 양 고유 항원의 규명에 대한 연구는 현재에도 지속적으로 행해지고 있으며, 종양항원의 효과적인 면역반응의 유도를 위하여 낮은 면역원성의 극복을 위한 면역증강제(adjuvant) 의 개념이 접목되어야 한다(Wolfers 등 2001; Miconnet 등 2002). 즉, 항원제시세포의 항원제시능의 증진에 의한 종양 살해활성을 가지는 CTL의 생산은 종양면역의 유도에서 가 장 중요한 요소이며, 따라서 선천면역계를 활성화시키는 기 능을 가진 adjuvant의 도입은 종양세포가 가지는 고유의 악 성종양 항원의 규명과 함께 항종양면역의 유도에 가장 중요 한 요소로 사료된다(Wolfers 등 2001; Miconnet 등 2002; Strome 등 2002)

한방에서 자인삼(刺人聯)이라 불리는 땃두릅은 두릅나무과 의 오갈피나무과에 속하는 낙엽성 관목이며, 국내에서 자생 하는 것은 Oplopanax elatus이고, 전통적으로 나무껍질 혹은 뿌리 껍질은 뿌리 껍질을 기침, 염증 및 류머티즘 등에 대하 여 사용하여 왔다(Kwon 등 2007). 그러나 국내에서 땃두릅에 대한 연구는 항산화 활성 및 독성시험 외에 다른 생리학적 활성에 대한 연구는 극히 제한적이었다(Kwon 등 2007; Yang 등 2010). 그러나 북미지역에서 자생하는 Oplopanax horriduse 에 대한 연구 결과, 땃두릅나무 껍질 추출물은 항세균, 항바 이러스 활성(McCutcheon 등 1992; McCutcheon 등 1995)을 가 지며, 추출물의 polycetylens 계열의 성분이 대장암 증식억제 활성이 보고되었다(Li 등 2010; Sun 등 2010). 그러나 땃두릅
추출물에 의한 면역자극 활성에 대한 연구는 미비하였다. 따 라서 본 연구는 국내산 자생 땃두릅나무 껍질 추출물의 면역 자극 활성을 조사함으로써 기능성 소재를 함유한 후보물질 로서의 가능성을 조사하기 위하여 실시하였다.

\section{재료 및 방법}

\section{1. 천삼 추출물 제조}

본 실험에 사용한 땃두릅나무(O. elatus)는 경기도 남양주 시 산야초 농원의 이의영 님으로부터 기증받아 사용하였다. 자연 건조된 땃두릅나무의 외피를 세절 후, 중량의 10 배 되는 증류수를 첨가한 후 $100^{\circ} \mathrm{C}$ 에서 2 시간 동안 가열하여 추출하였 다(Yoon 2008). 각 추출물은 원심분리(1,800×g, $30 \mathrm{~min}$ : Eppendorf, $\mathrm{NY}, \mathrm{USA}$ )를 통하여 상등액을 회수 후 동결건조(IIShin Lab., Seoul, Korea)하였다. 각각의 동결건조물은 $0.2 \mu \mathrm{m}$ 의 pore size 를 가지는 membrane filter(Whatman, Philadelphia, PA, USA)를 이용하여 filter한 다음, 시료(Oplopanax elatus $100^{\circ} \mathrm{C}$ extract; OeE$100)$ 를 제조하였고, $4^{\circ} \mathrm{C}$ 에 보관하면서 실험에 적용하였다.

\section{2. 실험동물}

생후 6 8주령의 자성 BALB/c 및 C57BL/6 마우스를 (주)오 리엔트에서 분양 받아 유한대학 실험동물장에서 사육하였다. 마우스는 사육조에 5 10마리씩 넣어 정수된 물과 실험동물 용 펠렛사료(Samyang Co Ltd, Incheon, Korea)를 자유 공급하 였고, 온도 $22^{\circ} \mathrm{C}$, 습도 $50 \%, 12$ 시간 간격으로 자동 조명되는 상태에서 스트레스를 받지 않도록 주의하여 사육하였다. 본 연구에서의 모든 동물실험은 유한대학교 동물실험윤리 위원 회의 승인(2009E-004)을 받아 실시하였다.

\section{3. 세포 배양 및 세포 독성}

종양세포의 배양을 위한 RPMI-1640과 Eagle's minimal essential medium(EMEM) 배지, fetal bovine serum(FBS), vitamin solution, non-essential amino acid, L-glutamic acid, thioglycollate 등은 Gibco(Carlsbad, CA, USA)사에서 구입하였다. 종양세포주인 colon26-M3.1 lung carcinoma 및 B16-BL6 melanoma의 배양은 $7.5 \%$ FBS, vitamin solution, sodium pyruvate, non-essential amino acid, L-glutamine이 함유된 EMEM 배지를, macrophage 및 lymphocytes의 배양은 7.5\% FBS가 함유된 RPMI-1640 배 지를 각각 이용하였으며 $5 \% \mathrm{CO}_{2}, 95 \%$ 습도 및 $37^{\circ} \mathrm{C}$ 의 배양 기(Thermo Fisher Scientific Inc. Waltham, USA)에서 배양하였 다. 시료의 종양세포에 대한 세포 독성 조사를 위하여 $5 \times 10^{3} /$ well의 밀도로 각 종양세포를 96-well plate의 각 well에 plating 한 후, 여러 농도의 시료를 첨가한 후 3 일간 배양하였다. 각 물질의 세포 독성 효과는 WST를 이용하는 cell counting kit 
(EZ-Cytox, Daeil Lab. Seoul, Korea)를 이용하여 제조사의 지 침에 따라 $450 \mathrm{~nm}$ 에서 흡광도(Molecular Device Co., Union City, USA)를 측정하였다.

\section{Macrophage로부터 생산된 Cytokine의 측정}

$\mathrm{BALB} / \mathrm{c}$ 마우스에 $3 \%$ thioglycollate를 $1 \mathrm{ml}$ 복강주사하고, 3 일 후에 경추탈골법으로 마우스를 희생시킨 후, 복강에 RPMI1640 배지 $10 \mathrm{~m} \ell$ 를 주입하여 복강 내 세포(peritoneal exudative cells; PEC)를 수집하였다. 수획한 PEC를 24 well culture plate 에 $1.5 \times 10^{6} / \mathrm{ml}$ 의 농도로 조정하여 분주하였다. 2 시간 동안 배 양하여 macrophage를 plate에 부착 후, 배양액으로 세척하여 부착되지 않은 세포를 제거 후, 세포 독성 효과를 나타내지 않는 $100 \mu \mathrm{g} / \mathrm{m} \ell$ 이하 농도의 OeE-100을 첨가하고, 24시간 동안 배양하였다. Cytokine 생산을 위한 양성대조군으로는 lipopolysaccharide(LPS; $1 \mu \mathrm{g} / \mathrm{m} \ell$, Sigma-Aldrich, St. Louis, MO, USA) 를 이용하였다. 배양완료 후, 배양 상등액에 유도 분비된 TNF- $\alpha$, IL-6 및 IL-12의 측정은 각 cytokine에 대한 ELISA kit(Pharmingen, San Jose, CA, USA)을 구입하여 제조사의 지침에 따라 측정하였다.

\section{NK-cell 활성 측정}

군당 2 마리의 6 주령의 $\mathrm{BALB} / \mathrm{c}$ 마우스에 100 및 $10 \mu \mathrm{g}$ 의 OeE-100을 정맥주사하고, 2일 후에 마우스의 비장을 멸균적 으로 취하여 비장세포(effector cell; E)를 준비하였다. U-bottomed 96-well plate에 마우스로부터 얻은 비장세포와 NK-sensitive 세포로 알려진 YAC-1 세포(target cell; T)를, E/T 비가 100:1이 되도록 조정하여 6시간 동안 배양하였다. 배양종료 후에 원 심분리를 통하여 배양상등액을 취한 후 살해된 암세포가 유 리한 $\mathrm{LDH}$ 의 양을 kit를 이용하여 제조사(Promega, Fitchburg, WI. USA)의 지침에 따라 측정하였다.

Cytotoxicity $(\%)=[($ experimental release - spontaneous release $) /$ (maximum release - spontaneous release) $] \times 100$

\section{6. 종양백신의 제조}

colon26-M3.1 carcinoma를 이용한 종양세포 백신은 기 발 표된 방법(Yoon 등 2008)으로 제조하였다. 약술하면, 배양 중 인 종양세포를 trypsin-EDTA를 이용하여 세포 배양 flask로부 터 분리 후, 배양배지를 넣고 1 회, 그 후 $\mathrm{PBS}$ 를 넣고 3 회 세척 함으로써 FBS 성분을 제거하였다. 종양백신의 제조는 세포 $\left(1 \times 10^{7} / \mathrm{m} \ell\right)$ 를 $\mathrm{PBS}$ 에 현탁 후, $100^{\circ} \mathrm{C}$ 에서 30 분간 중탕함으로 종양백신(BT-vaccine)을 제조하였다.

\section{7. 종양 전이 모델 및 백신의 면역}

OeE-100의 항종양 효과의 조사는 colon26-M3.1 carcinoma 혹은 B16-BL6 melanoma를 이용하는 실험동물(BALB/ 및 C57BL 6) 종양 전이 모델을 이용하였다. 시료의 투여는 혈관주사 (100 0.8 $\mu \mathrm{g} / \mathrm{mouse})$ 의 경우 암세포 투여 2일 전에 1 회, 경구투 여 $(2 \mathrm{mg} / \mathrm{mouse})$ 의 경우는 암세포 접종 10 일 전부터 매일 1회 투여하였다. 항종양 효과의 측정은 각 암세포를 접종하고, 14 일 후에 종양의 표적기관인 폐를 적출하여 Bouin's 용액에서 전 이된 종양을 고정시킨 후, 종양의 군집 수를 측정하였다. 종양 백신의 면역은 종양 접종 10 일 전에 $1 \times 10^{5}$ 로 제조된 melanoma T-vaccine 백신 단독 혹은 시료인 OeE-100(100 $\mu \mathrm{g})$ 를 C57BL/6 마우스에 피하주사법(s.c.)으로 1회 면역하였다.

\section{8. 통계처리}

대조군에 대한 실험군 간의 통계적 유의성은 Exel program (2003)을 이용하는 Student's two-tailed t-test로 분석하였다.

\section{결과 및 고찰}

\section{1. 땃두릅 추출물의 예방적 투여에 의한 종양 전이 억제 효과}

땃두릅 추출물인 OeE-100의 항 종양활성은 B16-BL6 melanoma 및 colon26- M3.1 carcinoma를 이용한 동물실험모델을 이용 하여 조사하였다. B16-BL6 melanoma를 이용한 실험동물 전이 모델에서 종양 접종 2일 전에 각 마우스에 0.8 100 $\mu \mathrm{g}$ 의 OeE-100을 1 회 정맥 투여한 결과, 투여농도 의존적인 종양 전이 억제 활성을 보였으며, 이 용량의 투여는 마우 스에서 외형상 어떠한 부작용도 관찰되지 않았다. OeE-100 을 종양 접종 전에 각각 100,20 , 및 $4 \mu \mathrm{g}$ 의 투여 결과, 각 각 $92.2 \%, 58.2 \%$ 및 $56.5 \%$ 의 종양 전이 억제활성을 보였 다(Fig. 1). 한편, colon26-M3.1 carcinoma 모델에서 $4 \mu \mathrm{g}$ 의 OeE- 100 을 혈관주사한 결과, $57.0 \%$ 의 종양 억제 효과를 보 였으며, $2 \mathrm{mg}$ 의 OeE-100을 2일 간격으로 총 10 회 경구투여 한 결과, $74.9 \%$ 의 높은 종양 전이 억제활성을 보였다(Table 1). 따라서 국내산 자생 땃두릅 추출물은 전신 및 경구투여 모두에서 유의한 종양 전이 억제활성을 있음을 확인하였 다. 한편, 땃두릅을 $4^{\circ} \mathrm{C}$ 로 추출한 경우도 유의한 종양 전이 억제 활성을 보였으나, $100^{\circ} \mathrm{C}$ 로 추출한 $\mathrm{OeE}-100$ 의 경우가 더 우수한 결과를 보였다(결과 미제시). 종양 전이 모델에 서 생약의 투여에 의한 종양 전이 억제효과는 세포 독성 혹은 macrophage 혹은 NK-세포 등의 선천면역계가 활성화 에 기인되는 효과임은 잘 보고되어 있는 바(Yoon 등 2003; Chino 등 2005; Weiss 등 2007), 본 시료의 투여에 의한 세 포 독성 효과 및 선천면역기구의 활성화에 대한 연구가 요 구되었다. 


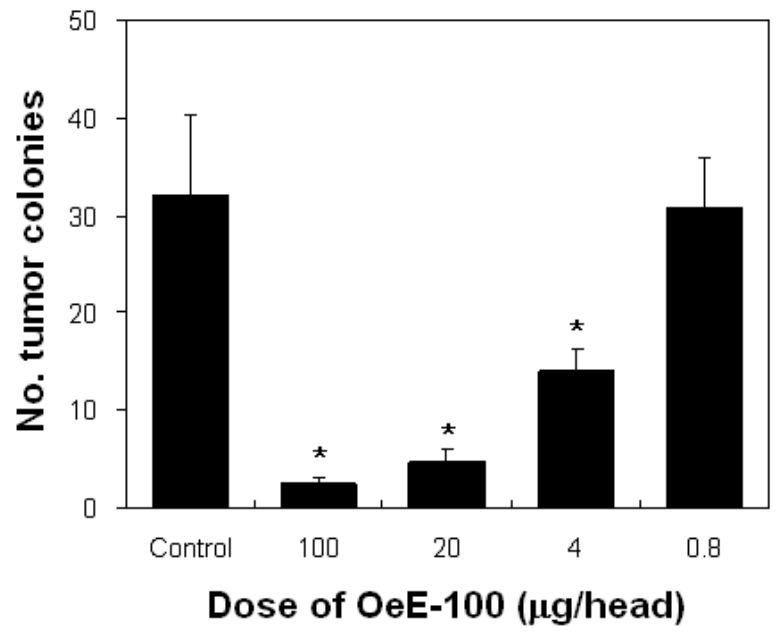

Fig. 1. Effect of Oplopanax elatus extract on the tumor metastasis. Groups of five C57BL/6 mice were inoculated B16-BL6 melanoma cells. All mice were administered i.v. with the indicated doses of the sample 2 days before tumor inoculation, and sacrificed 14 days after tumor inoculation for evaluation. ${ }^{*} p<0.001$, compared with the untreated group (by Student's two tailed $t$-test)

Table 1. Effect of Oplopanax elatus extracts on the tumor metastasis

\begin{tabular}{ccc}
\hline \hline Treatment & No. of tumor colonies & $\begin{array}{c}\text { Mean } \pm \text { S.D. } \\
\text { (Inhibition \%) }\end{array}$ \\
\hline Tumor control & $79,84,107,103,104$ & $95.4 \pm 12.9$ \\
i.v.(4 $\mu \mathrm{g} /$ mouse) & $45,35,30,50,45$ & $41.0 \pm 8.2(57.0)^{*}$ \\
p.o.(2 mg/mouse) & $33,23,23,29,12$ & $23.9 \pm 7.4(74.9)^{*}$ \\
\hline
\end{tabular}

Groups of five BALB/c mice that were given i.v. or oral(p.o.) administration 2 day before colon26-M3.1 tumor cell inoculation at the indicated doses of Oplopanax elatus extracts, and euthenized 14 days after tumor inoculation for evaluation. ${ }^{*}<0,001$, compared with the tumor control group(by Student's two tailed $t$-test)

\section{2. 땃두릅 추출물의 세포 독성 효과}

OeE-100의 B16-BL6 melanoma 및 colon26-M3.1 carcinoma 세포주에 대한 세포 독성 효과를 in vitro에서 조사하였다(Fig. 2). 암세포의 증식을 $50 \%$ 억제하는 $\mathrm{IC}_{50}$ 농도를 조사한 결과, OeE-100은 colon26-M3.1 carcinoma 및 B16-BL6 melanoma 종 양세포주에 대하여 각각 약 $100 \mu \mathrm{g} / \mathrm{ml}$ 및 $150 \mu \mathrm{g} / \mathrm{ml}$ 인 결과 를 보였으며, 두 세포주 모두 $62.5 \mu \mathrm{g} / \mathrm{m} \ell$ 이하의 농도에서 세 포의 증식에 영향을 주지 않았다. 북미산 땃두릅(Oplopanax horriduse) 성분의 세포 독성 효과에 대한 기존의 연구 결과, $\mathrm{Li}$ 등(2010)은 70\% ethanol 추출물의 경우 사람의 대장암세포 주인 HT-29, HCT 116 cell line에 대하여 추출물 10 100 $\mu \mathrm{g} /$

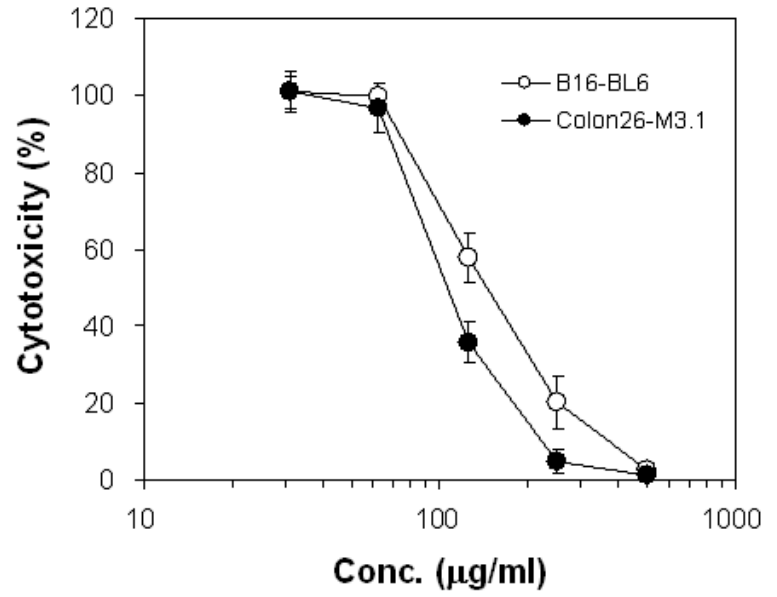

Fig. 2. Effect of Oplopanax elatus extract on the growth of tumor cells. Colon26-M3.1 carcinoma and B16-BL6 melanoma were coincubated with the indicated doses of Oplopanax elatus extract for $72 \mathrm{~h}$. The proliferation of these cells was measured by a cell counting kit described in Materials and Methods

$\mathrm{ml}$ 에서 세포 독성이 있다고 보고하였으며(Li 등 2010), Sun 등(2010)은 세포 독성 효과를 가지는 소수성의 polyacetylenes 성분을 분리하였다. 한국산 땃두릅인 Oplopanax elatus 추출 물의 세포 독성 효과를 북미산 추출물과 직접 비교할 수는 없지만, 세포 독성 효과를 가지는 성분은 유사할 가능성이 있 음을 배제할 수는 없었다. 앞으로 한국산 땃두릅의 소재 활용 을 위하여 세포 독성 활성을 가지는 성분 및 세포 독성에 대 한 자세한 기전에 대한 자세한 검토가 요구되었다.

\section{3. 땃두릅 추출물의 대식세포 활성화}

여러 가지 종양세포를 마우스 혈관에 주사하는 실험전이 모델에서 OeE-100의 예방적 투여는 암세포의 전이를 유의하 게 억제하였다(Fig. 1 및 Table 1). 이 결과는 혈관에 투여된 암세포가 그들의 목표기관(target organ)인 폐(lung)에 부착 (adhesion) 후 증식되기 전에 투여된 시료에 의하여 이미 활성 화된 cytolytic macrophage, NK-cell 등의 암세포에 대한 작동 세포(effector cells)에 의해 살해되기에 나타나는 현상으로 사료되었다(Chino 등 2005). 이러한 작동세포의 활성은 주 로 대식세포가 생산하는 cytokine들에 의하여 조절되고 있다 (Trinchieri G 1995; Gough 등 2001). OeE-100의 면역자극 효 과를 macrophage로부터 cytokines의 유도능으로 조사하기 위 하여 macrophage를 각 시료로 자극 후, 배양 상등액에 생산된 cytokine의 유도능을 조사한 결과, OeE-100은 macrophage로부 터 TNF- $\alpha, \mathrm{IL}-6$ 및 IL-12 등의 cytokines을 농도 의존적으로 생 산함으로써 면역반응의 개시단계인 대식세포와 같은 선천적 

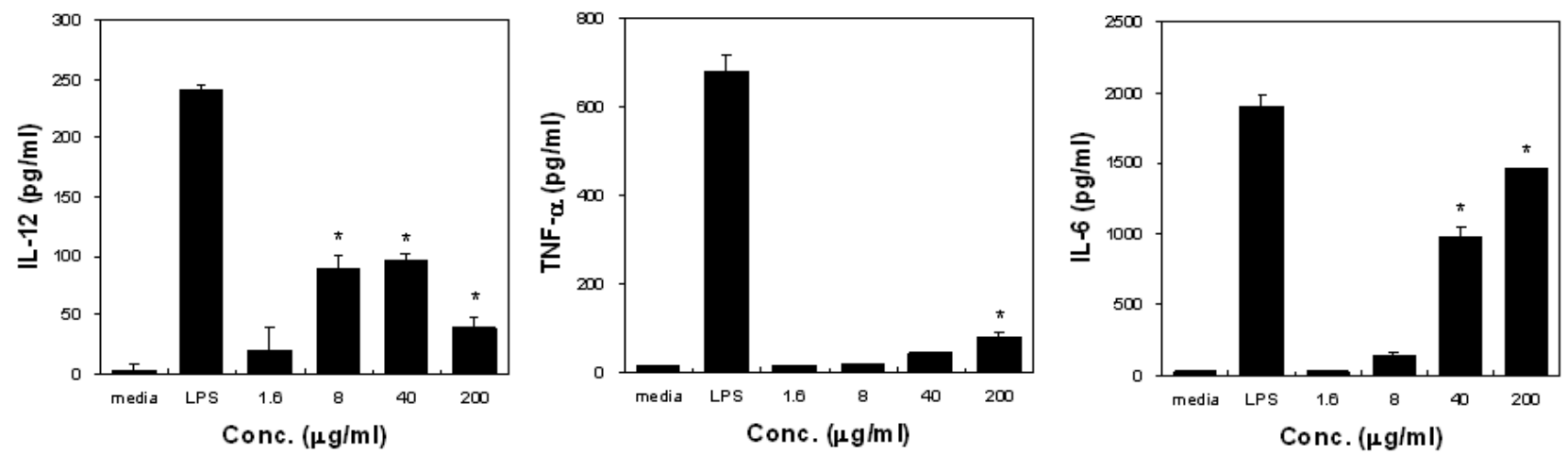

Fig. 3. Effect of Oplopanax elatus extract on production of cytokines from macrophages. Peritoneal macrophages were treated with the indicated doses of samples in 24-well plate for $24 \mathrm{hr}$. The level of each cytokine in the supernatants of the cultures was determined by ELISA kits. ${ }^{*} p<0.01$, compared with the media treated group by Student's two-tailed $t$-test

면역계(innate immune system)를 직접 활성화시키는 능력이 있음을 확인하였다(Fig. 3). Macrophage로부터 생산되는 염증 성 cytokine인 TNF- $\alpha$ 는 대표적인 muti-functional cytokine으 로서 IL- $1 \beta$ 와 함께 작용하여 면역관련 세포를 염증 부위에 모이게 하고, $\mathrm{T}$-세포의 분화 및 증식에 관여함으로써 암의 억 제에 있어 중요한 작용을 하는 것으로 알려져 있다(Knutson 등 2005; Weiss 등 2007). IL-6는 염증을 유발하여 macrophage 를 포함하는 식세포(phagocytes)의 탐식작용(phagocytosis) 및 보체의 생산을 증진시키는 기능을 가진다(Inatsu 등 2009). TNF- $\alpha$ 및 IL-6와 같은 염증성 cytokine들은 암의 전이 촉진 등과 같이 암의 증식에도 관여함이 알려져 있어, 항종양의 유 도와 관련하여 긍정적 혹은 부정적 요인을 모두 가지고 있으 며, 과도한 이들 염증성 cyytokine들의 생산은 암의 증식을 촉 진하기도 하기에 항종양 활성에 부정적 요소로 작용할 가능 성도 있다(Knutson \& Disis 2005; Dethlefsen 등 2013). IL-12는 면역반응의 초기단계에서 생산되는 cytokine으로서 IFN- $\gamma$ 의 생산에 직접관여하며, 따라서 세포 독성 $\mathrm{T}$ 세포(cytotoxic $\mathrm{T}$ lymphocyte; CTL)를 유도하는 세포성 면역의 매개자로서의 역할 뿐 아니라 암세포의 존재 시 암세포에 작용하는 NK-cell 의 활성화에 직접 관여함으로써 항암활성의 유도에서 가장 중요한 cytokine의 하나로 인정되고 있다(Trinchieri G 1995; Watford 등 2003; Weiss 등 2007). 따라서 땃두릅 추출물의 종 양 전이 억제활성은 주로 NK-cell의 종양세포 살해력 증진이 중요한 작동기구의 하나가 될 것으로 생각되었다(Yoon 등 2003; Chino 등 2005).

\section{4. 땃두릅 추출물 투여에 의한 NK-세포의 활성화}

$\mathrm{NK}$-세포는 주로 혈액에 존재하는 세포로서 바이러스 감염 세포 혹은 암세포 등의 비자기(non-self) 세포를 살해하는 세포 성 면역활성을 가지고 있으며, macrophage가 생산하는 cytokine
중의 하나인 IL-12에 의하여 종양세포를 살해하는 작동력을 획득하게 된다(Watford 등 2003; Weiss 등 2007). 동시에 활성 화된 NK-cells는 IFN- $\gamma$ 를 생산함으로써 macrophage를 활성 화시킴으로 종양에 대하여 대항하게 된다(Trinchieri G 1995; Watford 등 2003). 시료에 의한 NK-cell 활성화 조사는 시료가 주사된 마우스의 비장세포와 NK-sensitive 세포로 알려진 YAC-1 세포를 동시 배양 후, YAC-1의 살해 정도를 측정하였 다. NK-cell의 활성화 측정을 위한 OeE- 100 의 투여 용량은 마 우스에 각각 100,10 및 $1 \mu \mathrm{g}$ 을 각각 혈관주사 하였다. Fig. 4

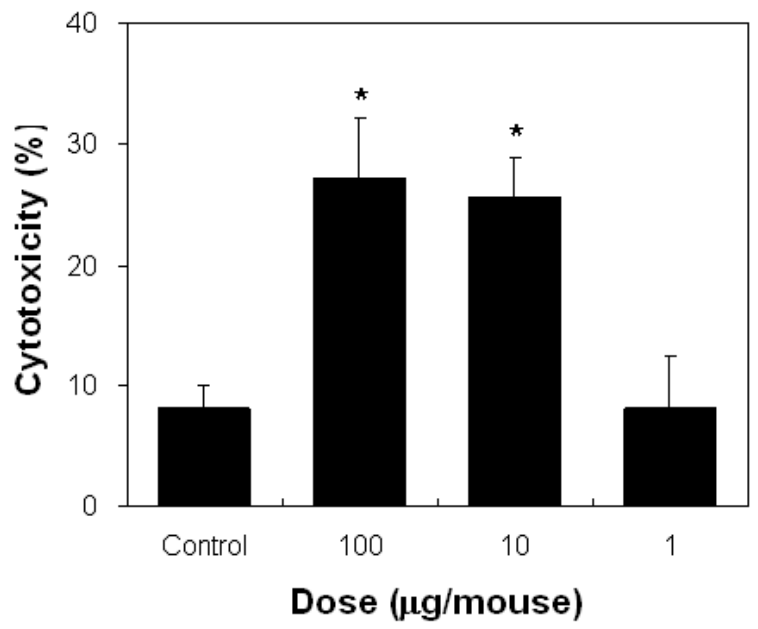

Fig. 4. Effect of Oplopanax elatus extract on the enhancement of NK cell activity. Two BALB/c mice per group were administered i.v. with Oplopanax elatus extract. NK activity was determined by the cytotoxicity assay using splenocytes (effector) and Yac-1 cells(target) on 2 days after Oplopanax elatus extract treatment as described in Materials and Methods. ${ }^{*} p<0.01$, compared with the control group by Student's two- tailed $t$-test 
의 결과에 나타낸 바와 같이, OeE- $100(100$ 및 $10 \mu \mathrm{g})$ 을 정맥 주사하고, 2 일이 경과된 마우스의 비장세포는 대조군의 정상 마우스의 비장세포에 비하여 YAC-1의 살해효과를 약 2배 정 도 증진시키는 결과를 보였다. 한편, $1 \mu \mathrm{g}$ 의 투여군은 유의한 NK-cell의 종양세포 살해활성이 유도되지 않음으로서 OeE-100 의 혈관주사에 의한 NK-cell을 활성화시키는 용량은 Table 1 의 암전이 억제효과와 유사한 경향을 보였다. 따라서 OeE-100 의 투여에 의한 항종양 활성은 OeE- 100 의 투여에 의하여 $\mathrm{NK}$-cell의 종양세포 살해활성 증가가 중요한 원인 중 하나 이며, 이것은 시료에 의하여 자극받은 macrophage가 생산하는 cytokine의 영향을 받았을 것으로 사료되었다(Yoon 등 2003; Chino 등 2005).

\section{5. 땃두릅 추출물의 종양면역 증진 효과}

종양을 포함하는 여러 가지 항원에 대한 항원제시작용을 포함하는 선천면역계의 자극이 종양특이적 면역반응을 유도 한다는 것은 잘 알려져 있다(Trinchieri 등 1995; Strome 등 2002). 본 실험은 선천면역 자극효과에 의하여 항종양 활성이 인정된 땃두릅 추출물이 종양세포에 대한 면역증강활성을 유도되는지 확인하고자 실시하였다. 즉, B16-BL6 세포주로 제조된 종양백신인 BT-vaccine의 예방적 면역에서 OeE-100 를 BT-vaccine과 동시에 면역할 경우, 항종양활성이 백신단독 면역의 경우와 비교하여 더 높은 항종양 활성이 유발되는지 검토하였다(Fig. 5). 항종양활성을 일으키기 위한 BT-vaccine 의 면역은 1 회 면역(피하주사)하였고, 면역 2주 후에 암세포

\section{(A) Anti-metastatic activity}

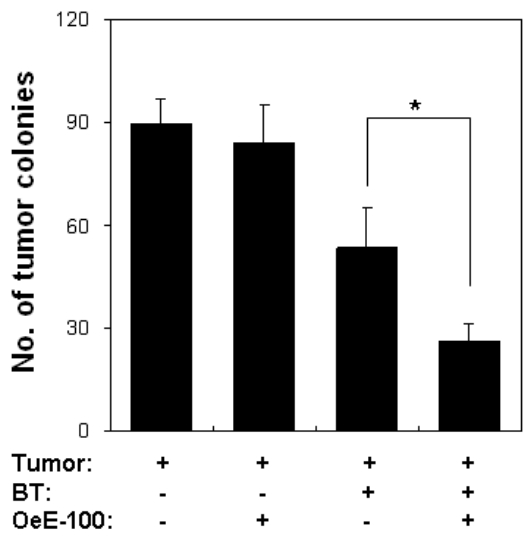

(melanoma)를 혈관주사 하였다. 실험 결과, 종양 대조군에 비 하여 BT-vaccine 만을 1회 면역한 결과, 종양대조군에 비하여 $40.2 \%$ 의 억제효과를 보였으며, BT-vaccine에 OeE-100 (100 $\mu \mathrm{g})$ 을 혼합하여 면역한 결과, 약 $70.9 \%$ 의 항종양 활성을 보였 다. 이러한 결과는 OeE-100가 BT-vaccine의 면역에 의한 항종 양면역반응을 증진시키는 adjuvant로서의 기능을 한 것으로 판단되었다(Miconnet 등 2002; Strome 등 2002; Han 등 2012). 항종양 활성을 증진시키는 adjuvant 활성은 macrophage 혹은 $\mathrm{DC}$ 등의 항원제시세포의 항원제시능이 증가함으로 유도된다 (Gough 등 2001; Knutson \& Disis 2005). 항원제시세포의 항원 제시능은 보조자극인자(co-stimulatory molecule) 발현 및 항종 양활성의 유발에 직접적으로 관여하는 Th1 type의 면역반응 을 증가시키는 IL-12의 생산이 중요한 요인 중의 하나로 인정 되고 있다(Wolfers 등 2001; Ahmad 등 2004; Weiss 등 2007). Fig. 3의 결과에서 OeE-100은 silica induced macrophage를 직 접 자극하여 $\mathrm{IL}-12$ 를 생산하는 cytokine inducer로서의 기능이 있었던 바, OeE- 100 의 종양면역 증진효과는 CTL의 기능을 증진하는 IL-12 생산기능이 관여될 것으로 사료되었다(Wolfers 등 2001; Miconnet 등 2002; Strome 등 2002). BT-vaccine의 면 역에 의한 종양면역 증진효과에 대한 기존의 보고는 주로 IFN- $\gamma$ 와 같은 Th1 type cytokine 생산에 의한 CTL의 종양세 포 살해활성 증진효과가 종양의 전이를 억제하는 가장 중요 한 요인임을 보고한 바 있다(Yoon 등 2008; Han 등 2012). 따 라서 $\mathrm{OeE}-100$ 의 종양면역 증진효과 기구를 설명하기 위하여 각 면역 마우스의 T-cell이 생산하는 IFN- $\gamma$ 의 생산양식을 조사

\section{(B) IFN- $\gamma$ production}

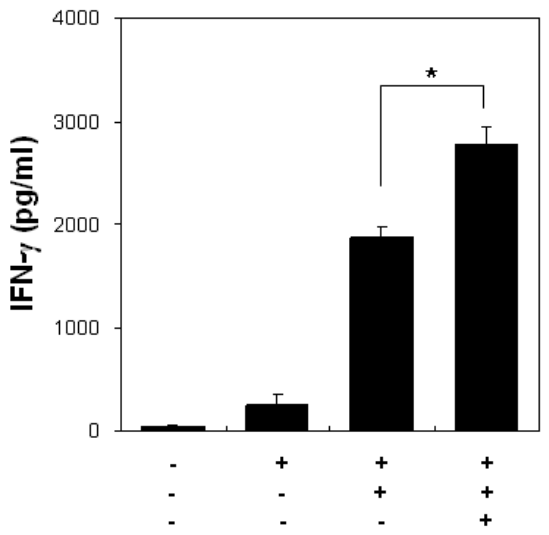

Fig. 5. Effect of tumor specific immunoadjuvant activity of Oplopanax elatus extract. (A) Inhibition of tumor metastasis following vaccination with BT-vaccine(BT) and Oplopanax elatus extract. Five BALB/c mice per groups of mice were vaccinated s.c. and inoculated i.v. with colon26-M3.1 carcinoma cells 14 days after final vaccination and killed 14 days after tumor inoculation for evaluation. (B) IFN- $\gamma$ production from splenocytes of mice immunized with BT-vaccine and Oplopanax elatus extract. The splenocytes of each immunized groups were collected from mice and cultured for three days. The levels of cytokines in the culture supernatant were measured using an each ELISA kit. * $p<0.01$, compared with the indicated group by Student's two-tailed $t$-test 
하였다. 즉, 정상마우스, 암세포만 접종한 마우스, BT-vaccine 혹은 BT-vaccien+OeE-100을 면역 후, 종양세포를 접종한 마 우스로부터 얻은 비장세포를 3 일간 배양 후 배양상등액에 생 산된 IFN- $\gamma$ 의 생산을 조사하였다. 그 결과, 정상마우스 및 종양만을 접종한 마우스는 각각 $42 \pm 19$ 및 $262 \pm 99 \mathrm{pg} / \mathrm{m} \ell$ 의 IFN- $\gamma$ 을 생산한 반면, BT-vaccine 혹은 BT-vaccine+OeE-100 을 면역한 마우스의 비장세포는 각각 $1,870 \pm 106$ 및 2,779 \pm 171 $\mathrm{pg} / \mathrm{m} \ell$ 의 IFN- $\gamma$ 를 생산하였다. BT-vaccine 면역 후 암세포를 접종한 마우스의 비장세포가 암세포만을 접종한 마우스의 비장세포에 비하여 암세포 재자극 없이 높은 IFN- $\gamma$ 의 생산 성을 보인 것은 BT-vaccine이 접종한 암세포에 대하여 높은 세포성 면역반응을 유도하고 있는 것으로 사료되었다(Yoon 등 2008). 동시에 OeE-100을 동시에 면역한 경우 BT-vasccine 단독의 면역 경우보다 더 높은 IFN- $\gamma$ 의 생산효과가 나타난 것은 앞서 OeE-100이 BT-vaccine의 면역에 의한 종양면역반 응을 증진시키는 기능을 지지하는 결과로 해석할 수 있었다 (Miconnet 등 2002; Strome 등 2002; Knutso \& Disis 2005). 따 라서 BT-vaccine에 OeE-100을 동시에 면역한 결과, 얻어진 항 암작용 증진효과는 주로 $\mathrm{OeE}-100$ 이 주로 종양세포에 대한 T세포 매개의 면역반응을 증진시키는 기능이 있을 것으로 사 료되었다(Miconnet 등 2002; Bisht 2010; Han 등 2012).

\section{결 론}

땃두릅 추출물의 항종양 및 면역증강 활성에 대하여 조사 하였다. $100{ }^{\circ} \mathrm{C}$ 의 물로 추출한 땃두릅 추출물인 $\mathrm{OeE}-100$ 의 colon26-M3.1 carcinoma 및 B16-BL6 melanoma에 대한 세포 독성 효과를 조사한 바, $62.5 \mu \mathrm{g} / \mathrm{m} \ell$ 이하의 농도에서 세포 독 성을 나타내지 않았다. 실험동물 전이모델에서 $\mathrm{OeE}-100$ 의 혈관 $(4 \sim 100 \mu \mathrm{g})$ 및 경구 $(2 \mathrm{mg})$ 투여는 colon26-M3.1 carcinoma 및 B16-BL6 melanoma에 의한 종양의 전이를 농도 의존적으 로 억제하였다. OeE-100은 대식세포를 직접 자극하여 TNF$\alpha$, IL-6 and IL-12를 생산하는 cytokine inducer로의 작용이 있었다. 마우스에 OeE-100(10 100 $\mu \mathrm{g} / \mathrm{mouse})$ 을 혈관주사 후 얻은 비장세포는 YAC-1 세포주에 대한 세포살해 활성을 가 짐으로서 NK-cell 활성을 증진시키는 기능이 있었다. 종양백 신인 BT-vaccine에 OeE-100을 동시에 면역한 경우, 종양백신 단독의 면역 경우에 비하여 높은 항종양 활성을 나타냈다. 동 시에 BT-vaccine에 OeE-100을 동시에 면역 후 암을 접종한 마 우스의 비장세포는 종양백신 단독 면역군에 비하여 유의하 게 높은 IFN- $\gamma$ 를 생산하였다. 본 결과로부터 땃두릅 추출물 은 마우스에서 종양세포에 대한 선천면역 및 획득면역의 활 성화를 유발하는 기능성 소재로서 개발 가능성이 있음을 제 시하였다.

\section{감사의 글}

이 연구는 2012학년도 유한대학교 학술연구비의 지원으로 연구되었음.

\section{References}

Ahmad M, Rees RC, Ali SA. 2004. Escape from immunotherapy: possible mechanisms that influence tumor regression/progression. Cancer Immunol Immunother 53:844-854

Bisht M, Bist SS, Dhasmana DC. 2010. Biological response modifiers: current use and future prospects in cancer therapy. Indian $J$ Cancer 247:443-451

Chino A, Sakurai H, Choo MK, Koizumi K, Shimada Y, Terasawa K, Saiki I. 2005. Juzentaihoto, a kampo medicine, enhances IL-12 production by modulating toll-like receptor 4 signaling pathways in murine peritoneal exudate macrophages. Int Immunopharmacol 5:871-882

Dethlefsen C, Hojfeldt G, Hojman P. 2013. The role of intratumoral and systemic IL-6 in breast cancer. Breast Cancer Res Treat 138:657-664

Fisher M, Yang LX. 2002. Anticancer effects and mechanisms of polysaccharide-K (PSK): implications of cancer immunotherapy. Anticancer Res 22:1737-1754

Gough MJ, Melcher AA, Ahmed A, Crittenden MR, Riddle DS, Linardakis E, Ruchatz AN, Emiliusen LM, Vile RG. 2001. Macrophages orchestrate the immune response to tumor cell death. Cancer Res 61:7240-7247

Gutzmer R, Li W, Sutterwala S, Lemos MP, Elizalde JI, Urtishak SL, Behrens EM, Rivers PM, Schlienger K, Laufer TM, Eck SL, Marks MS. 2004. A tumor-associated glycoprotein that blocks MHC class II dependent antigen presentation by dendritic cells. J Immunol 173:1023-3102

Han KH, Kim DH, Song KY, Lee KH, Kang TB, Yoon TJ. 2012. Enhancement of anti-tumor immunity by administration of Macrolepiota procera extracts. Kor J Pharmacogn 43: 32-38

Inatsu A, Kinoshita M, Nakashima H, Shimizu J, Saitoh D, Tamai S, Seki S. 2009. Novel mechanism of C-reactive protein for enhancing mouse liver innate immunity. Hepatology 49: 2044-2054

Kim AJ, Han MR, Lee SJ. 2012. Antioxidative capacity and quality characteristics of Yanggaeng using fermented red ginseng for the elderly. Korean J Food \& Nutr 25:83-89 
Knutson KL, Disis ML. 2005. Tumor antigen-specific T helper cells in cancer immunity and immunotherapy. Cancer Immunol Immunother 54:721-728

Kwon HS, Kim DH, Shin HY, Yu CY, Kim MJ, Lim JD, Park JK, Kim JK. 2007. Fourteen-day repeated-dose oral toxicity study of the ethanol extracts isolated from Oplopanax elutus in Sprague-Dawley rat. Korean J Food Sci Technol 39: 470-475

Li XL, Sun S, Du GJ, Qi LW, Williams S, Wang CZ, Yuan CS. 2010. Effects of Oplopanax horridus on human colorectal cancer cells. Anticancer Res 30:295-302

McCutcheon AR, Ellis SM, Hancock RE, Towers GH. 1992. Antibiotic screening of medicinal plants of the British Columbian native peoples. J Ethnopharmacol 37:213-223

McCutcheon AR, Roberts TE, Gibbons E, Ellis SM, Babiuk LA, Hancock RE, Towers GH. 1995. Antiviral screening of British Columbian medicinal plants. J Ethnopharmacol 49: $101-110$

Miconnet I, Koenig S, Speiser D, Krieg A, Guillaume P, Cerottini JC, Romero P. 2002. CpG are efficient adjuvants for specific CTL induction against tumor antigen derived peptide. $J$ Immunol 168:1212-1218

Murray HW, Nathan CF. 1999. Macrophage microbicidal mechanisms in vivo: reactive nitrogen versus oxygen intermediates in the killing of intracellular visceral Leishmania donovani. J Exp Med 189:741-746

Oh SI, Lee MS. 2012. Antioxidative and antimutagenic effects and hyperplasia inhibitory activity of cancer cells from $L u f f a$ cylindrica extracts. Korean J Food \& Nutr 25:888-896

Ohno N, Furukawa M, Miura NN, Adachi Y, Motoi M, Yadomae T. 2001. Antitumor beta glucan from the cultured fruit body of Agaricus blazei. Biol Pharm Bull 24:820-828

Stauder H, Kreuser ED. 2002. Mistletoe extracts standardised in terms of mistletoe lectins (ML I) in oncology: current state of clinical research. Onkologie 25:374-380

Strome SE, Voss S, Wilcox R, Wakefield TL, Tamada K, Flies D, Chapoval A, Lu J, Kasperbauer JL, Padley D, Vile R,
Gastineau D, Wettstein P, Chen L. 2002. Strategies for antigen loading of dendritic cells to enhance the antitumor immune response. Cancer Res 62:1884-1889

Sun S, Du GJ, Qi LW, Williams S, Wang CZ, Yuan CS. 2010. Hydrophobic constituents and their potential anticancer activities from Devil's Club (Oplopanax horridus Miq.). J Ethnopharmacol 132:280-285

Trinchieri G. 1995. Interleukin-12: A proinflammatory cytokine with immunoregulatory functions that bridge innate resistance and antigen-specific adaptive immunity. Annu Rev Immunol $13: 251-276$

Wasser SP. 2002. Medicinal mushrooms as a source of antitumor and immunomodulating polysaccharides. Appl Microbiol Biot 60:258-274

Watford WT, Moriguchi M, Morinobu A, O'Shea JJ. 2003. The biology of IL-12: coordinating innate and adaptive immune responses. Cytokine Growth Factor Rev 14:361-368

Weiss JM, Subleski JJ, Wigginton JM, Wiltrout RH. 2007. Immunotherapy of cancer by IL-12-based cytokine combinations. Expert Opin Biol Ther 7:1705-1721

Wolfers J, Lozier A, Raposo G, Regnault A, Thery C, Masurier C, Flament C, Pouzieux S, Faure F, Tursz T, Angevin E, Amigorena S, Zitvogel L. 2001. Tumor derived exosomes are a source of shared tumor rejection antigens for CTL cross-priming. Nat Med 7:297-303

Yang MC, Kwon HC, Kim YJ, Lee KR, Yang HO. 2010. Oploxynes A and B, polyacetylenes from the stems of Oplopanax elatus. J Nat Prod 73: 801-805

Yoon TJ 2008. Effect of water extracts from root of Taraxacum officinale on innated and adoptive immune response in mice. Korean J Food \& Nutr 21:275-282

Yoon TJ, Kim JY, Kim H, Hong C, Lee H, Lee CK, Lee KH, Hong S, Park SH. 2008. Anti-tumor immunostimulatory effect of heat-killed tumor cells. Exp Mol Med 40:130-144

$$
\begin{aligned}
& \text { 접 수 : 2013년 6월 25일 } \\
& \text { 최종수정 : 2013년 7월 31일 } \\
& \text { 채 택: 2013년 8월 7일 }
\end{aligned}
$$

